\title{
Effects of Dietary Supplementation of Inorganic, Organic and Nano Selenium on Antioxidant Status of Giriraja Chicken
}

\author{
S. Prasoon ${ }^{1 *}$, Jayanaik ${ }^{1}$, V. Malathi ${ }^{2}$, C.S. Nagaraja $^{3}$ and H.D. Narayanaswami ${ }^{4}$ \\ ${ }^{1}$ Department of Poultry Science, ${ }^{2}$ Department of Livestock Production Management, ${ }^{3}$ AICRP \\ on Poultry, Veterinary College, Bangalore, Karnataka, India \\ ${ }^{4}$ Karnataka Veterinary and Animal Sciences University, Bidar, Karnataka, India \\ *Corresponding author
}

\begin{tabular}{l} 
Ke y w o r d s \\
$\begin{array}{l}\text { Anti-oxidant, GPx, } \\
\text { SOD, CAT, TBARS, } \\
\text { Giriraja, Nano } \\
\text { selenium, Organic } \\
\text { selenium }\end{array}$ \\
\hline Article Info \\
\hline $\begin{array}{l}\text { Accepted: } \\
\text { 12 July } 2018 \\
\text { Available Online: } \\
10 \text { August } 2018\end{array}$ \\
\hline
\end{tabular}

\section{Introduction}

Selenium (Se) is an essential trace mineral having a number of biologically important roles in poultry such as regulation of antioxidants activities, improvement of immune functions, normal growth and body maintenance (Surai, 2002). Sodium selenite as an inorganic form is the most common source

\section{A B S T R A C T}

An experiment was designed to investigate the effects of supplementing inorganic, organic and nano selenium on growth performance and antioxidant status of Giriraja chicken reared in deep litter system up to eight weeks of age. A total of 384 day old straight run chicks were equally divided into eight treatment groups with four replicates each. Control group $\left(T_{1}\right)$ was fed with basal broiler diet (NRC, 1994) without added selenium supplementation in premix. Experimental groups $T_{2}$ and $T_{3}$ were given basal diet supplemented with Sodium selenite to contain selenium concentration of $150 \mathrm{ppb}$ and 300 $\mathrm{ppb}$, respectively in the experimental feed. Selenium concentration of $150 \mathrm{ppb}$ and $300 \mathrm{ppb}$ using selenium yeast is added to basal diet to form experimental diet for $T_{4}$ and $T_{5}$. Experimental groups $\mathrm{T}_{6}, \mathrm{~T}_{7}$ and $\mathrm{T}_{8}$ were fed on basal diet containing 50ppb, 150ppb and $300 \mathrm{ppb}$ selenium supplemented with nano selenium. Standard management and vaccination procedures were followed throughout the study. Weekly cumulative body weight, feed intake and overall cumulative FCR were similar between treatment groups. Antioxidant enzymes GPx, SOD level were increased in liver with selenium supplementation than the control group while catalase activity was improved by $300 \mathrm{ppb}$ selenium supplementation irrespective of source. TBARS value recorded was significantly reduced in $150 \mathrm{ppb}$ and $300 \mathrm{ppb}$ organic and nano selenium supplemented groups. 
than inorganic forms (Kim and Mahan, 2001) and widely used as feed additive now a days.

Nanoparticles having size in nano scale at least in one dimension is getting importance as animal feed additive (Zhang et al., 2001). But, nano-materials have different physical and chemical characteristics compared to the bulk material (Hartemann et al., 2015). It is reported that nano-materials exhibit novel properties, like a high surface activity, a great specific surface area, a lot of surface active centers, and a high catalytic efficiency (Gao and Hiroshi, 2005). Due to both high surface reactivity and advantage of size effect, nanoparticle has been already used in pharmaceutical applications to increasing the bioavailability of drugs and targeting therapeutic agents to particular organs (Davda and Labhasetwar, 2002). It has been reported that nanoparticles showed new characteristics of transport and uptake and exhibited higher absorption efficiencies than their conventional counterparts (Zha et al., 2008; Liao et al., 2010).

The range between the minimum requirement and maximum tolerable level of Se is narrow. The NRC (1994) recommendations established a minimum level at $0.1 \mathrm{mg} / \mathrm{kg}$ of diet for Selenium supplementation for broilers. To ensure feed safety, maximum levels for Se in complete feeds of broilers have been set at $0.5 \mathrm{mg} / \mathrm{kg}$ in the European Union (2004). Diseases such as exudative diathesis and pancreatic fibrosis in chicks could be prevented by adequate dietary Se supplementation (Payne and Southern, 2005).

Selenium is an integral part of antioxidant enzyme Glutathione peroxidase (Rotruck et al., 1973) which is having an important biochemical role in removal of free radicals formed as a result of metabolism in tissues.Free radicals formed react with oxygen to form peroxides, which serve as the entry point to a multitude of reactions, producing numerous by-products and the decomposition of vital molecules and nutrients (Calabotta and Shermer, 1985). Antioxidant enzymes eliminate such free radicals before damage occurs (Sunde, 1994) to the molecules and to the tissues. Cai et al., (2012) reported that dietary supplementation with nano-selenium (NS) at 0.3 to $0.5 \mathrm{mg} / \mathrm{kg}$ in broilers significantly improved oxidation resistance of liver and muscles.

Considering these facts, a study was conducted to evaluate the growth performance and antioxidant status of Giriraja birds fed on varying levels of inorganic, organic and nano selenium up to eight weeks.

\section{Materials and Methods}

A total of 384 day old straight run Giriraja chicks were procured from Department of Poultry Science, Veterinary College, Bangalore and wing banded, weighed and randomly assigned to eight treatment groups with four replicates having 12 chicks in each group, in a randomized block design.

Giriraja birds are crossbred dual purpose chicken developed for backyard rearing by Department of Poultry Science, Veterinary College, Bangalore which have wide acceptance among farmers in India and in many developing countries. Giriraja birds reared on broiler feed are marketed at eight weeks for meat purpose, while birds fed on chick mash and layer feed or birds reared in backyard system by scavenging are used for egg production.

The chicks were reared in deep litter system with all standard managemental practices till eight weeks of age. Birds were immunized against Newcastle disease on day 7 and 21 and against Infectious Bursal Disease on day 14 and 28 , respectively. 
Experimental broiler diet in mash form with uniform particle size was formulated as per NRC (1994) specifications with varying selenium concentration as described in Table 1. Chicks were fed with experimental broiler prestarter feed till 21 days followed by experimental broiler starter feed from 22 to 42 days and experimental broiler finisher feed from 43 to 56 days of age. Continues uniform lighting was ensured in poultry house with natural and artificial lights during entire period of study. All the procedures and methods followed in this study were approved by Institutional Animal Ethics Committee of KVASU, Bidar.

Cumulative body weight and cumulative feed intake was recorded at the end of $3^{\text {rd }}, 6^{\text {th }}$ and $8^{\text {th }}$ weeks of age and cumulative feed conversion ratio (FCR) was calculated. Glutathione peroxidase activity (GPx), Superoxide dismutase activity (SOD), Catalase activity (CAT) in liver tissue and Thiobarbituric acid reactive substance (TBARS) value in breast muscle was estimated after slaughter of birds. Procedures are detailed in brief below,

Tissue preparation: Immediately after sacrificing the animals, the tissues were processed for the estimation of activity of antioxidant enzymes as per the method of Bruce and Baudry (1995). Ten per cent liver homogenate was made by homogenising $1 \mathrm{~g}$ liver tissue in $10 \mathrm{ml}$ of ice cold $0.05 \mathrm{M}$ phosphate buffer ( $\mathrm{pH}$ 7.4). The liver homogenate was centrifuged at $1500 \mathrm{~g}$ for 1 hour at $4^{\circ} \mathrm{C}$ and the supernatant obtained was used for the estimation of total proteins, superoxide dismutase, catalase and glutathione peroxidase levels. Protein content of the tissue was determined by the method described by Lowry et al., (1951).

SOD activity: Superoxide dismutase was determined by the method described by Marklund and Marklund (1974). Superoxide anion is an intermediate in the auto-oxidation of pyrogallol which occurs at $\mathrm{pH}$ 8.2. The ability of SOD to inhibit the auto-oxidation of pyrogallol at $\mathrm{pH} 8.2$ provides the basis for enzymatic activity. To $0.5 \mathrm{ml}$ of tissue homogenate, $0.25 \mathrm{ml}$ of ethanol and $0.15 \mathrm{ml}$ of chloroform were added and mechanically shaken for $15 \mathrm{~min}$. Then the contents were centrifuged at $13,000 \mathrm{~g}$ for $15 \mathrm{~min}$ at $4{ }^{\circ} \mathrm{C}$. The supernatant was carefully separated and used for the test. OD value of assay mixture consisted of $2 \mathrm{ml}$ of $0.1 \mathrm{M}$ TrisHCl, $0.5 \mathrm{ml}$ of homogenate, $1.5 \mathrm{ml}$ of distilled water and 0.5 $\mathrm{ml}$ of pyrogallol was taken for $3 \mathrm{~min}$ at 420 $\mathrm{nm}$ wavelength.

GPx activity: Glutathione peroxidase was determined by the method described by Rotruck et al., (1973). About $0.5 \mathrm{ml}$ of $0.4 \mathrm{M}$ phosphate buffer was taken and $0.1 \mathrm{ml}$ of sodium azide, $0.2 \mathrm{ml}$ of $4 \mathrm{mM} \mathrm{GSH}, 0.5 \mathrm{ml}$ tissue homogenate, $0.1 \mathrm{ml}$ of $30 \mathrm{mM} \mathrm{H} \mathrm{H}_{2} \mathrm{O}_{2}$ were added and the volume was made up to 2 $\mathrm{ml}$ with distilled water. It was incubated for 10 min in room temperature and the reaction was terminated by the addition of $0.5 \mathrm{ml} 10$ percent TCA and centrifuged at $4{ }^{\circ} \mathrm{C}$ for 10 $\mathrm{min}$ at $1500 \mathrm{rpm}$. To determine the residual glutathione content, the supernatant was removed and to this $4 \mathrm{ml}$ of $0.3 \mathrm{M}$ disodium hydrogen phosphate and $1 \mathrm{ml}$ dithiobisnitrobenzoic acid (DTNB) (0.004\%) reagent were added. The color developed was read at $412 \mathrm{~nm}$ against the reagent blank containing only phosphate solution and DTNB reagent.

CAT activity: Catalase was estimated by the method of Caliborne (1985). Catalase activity was determined by monitoring the decrease in absorbance spectrophotometrically at $240 \mathrm{~nm}$ due to decomposition of $\mathrm{H}_{2} \mathrm{O}_{2}$. The difference in extinction coefficient per unit time was a measure of the catalase activity. To $0.2 \mathrm{ml}$ of homogenate, $1 \mathrm{ml}$ of $30 \mathrm{mM} \mathrm{H}_{2} \mathrm{O}_{2}$ was added and the OD value was taken at $240 \mathrm{~nm}$ at an interval of $1 \mathrm{~min}$ for $3 \mathrm{~min}$. Blank used 
contained $0.2 \mathrm{ml}$ of distilled water plus $1 \mathrm{ml}$ of $30 \mathrm{mM} \mathrm{H}_{2} \mathrm{O}_{2}$.

TBARS: Thiobarbituric acid reactive substances (TBARS) value was estimated as per Witte et al., (1970) with slight modifications. Ten gram of sample was triturated with $25 \mathrm{~mL} 20 \%$ trichloroacetic acid (TCA) in $2 \mathrm{M}$ orthophosphoric acid solution for $2 \mathrm{~min}$. The content was taken into beaker and rinsed with $25 \mathrm{~mL}$ of water, mixed well and filtered through Whatman No. 1 filter paper. Three millilitres of TCA filtrate was mixed with equal volume of thiobarbituric acid (TBA) reagent $(0.005 \mathrm{M})$ and stored for 16 hours in adark room at $27^{\circ} \mathrm{C}$. Optical density (OD) value was recorded at $532 \mathrm{~nm}$ wavelength. TBARS value was calculated as $\mathrm{mg}$ malondialdehyde $/ \mathrm{kg}$ of sample by multiplying OD with $\mathrm{K}$ factor (5.2).

Statistical analysis: To determine the statistical significance, ANOVA technique described by Snedecor and Cohran (1994) was used. Differences between the means were tested using Duncan's Multiple Range Test (Duncan, 1995) at 5 per cent confidence level.

\section{Results and Discussion}

\section{Body weight}

Supplementation of Selenium as SS, SY and NS did not influence cumulative body weight between treatments and control groupon day 21, 42 and 56 of the study (Table 2). The results obtained in this study was in agreement with the results of Srimongkol et al., (2004), Niu et al., (2009), Da Silva et al., (2010), Cai et al., (2012), Tayeb and Quader (2012), Rao et al., (2013), Chen et al., (2014), Habibian et al., (2014) and Dalia et al., (2017) who observed no significant change in body weight of chicken due to dietary supplementation of organic selenium comparison to inorganic selenium. Similarly, supplementation of nano selenium did not produce any significant difference in cumulative body weight of Giriraja birds which was in agreement with Moghaddam et al., (2017), Gangadoo et al., (2018) and Li et al., (2018) who reported comparable body weight for broiler birds supplemented with organic and nano selenium in feed.

In contradictory to the results obtained in the present study, Ozkan et al., (2007), Upton et al., (2008), Yang et al., (2012), Rajashree et al., (2014), Selim et al., (2015), Xu et al., (2015), Wang et al., (2016), Ravindran and Elliott (2017) and Zia et al., (2017) reported increased body weight for broilers supplemented with organic source of selenium compared to inorganic source.

Zhou and Wang (2011), Bagheri et al., (2015), Mahmoud et al., (2016) and Bakhshalinejad et al., (2018) noticed higher body weight gain in chicken supplemented with nano selenium compared to other sources.

\section{Feed intake}

As shown in Table 3, cumulative feed intake on day 21,42 and 56 of the experiment was not affected by selenium supplementation. Results in the experiment was in agreement with the results published by Niu et al., (2009), Da Silva et al., (2010), Cai et al., (2012), Tayeb and Quader (2012), Chen et al., (2014), Habibian et al., (2014), Gogmen et al., (2016), Dalia et al., (2017), Moghaddam et al., (2017) and Li et al., (2018) who observed no significant difference in feed intake of chicken due to selenium supplementation.

Higher feed intake in dietary selenium supplemented groups were reported by Yang et al., (2012), Rajashree et al., (2014), Bagheri et al., (2015), Ravindran and Elliott (2017) and Zia et al., (2017) which was in opposition to the present study. 


\section{Feed conversion ratio}

Supplementation of selenium did not affect cumulative FCR in Giriraja birds (Table 4) which was in agreement with the study conducted by Tayeb and Quader (2012) and Da Silva et al., (2010) who reported that the dietary supplementation of inorganic and organic sources of selenium at varying levels resulted in no significant differences in feed conversion ratio in broiler chicken. Similarly research conducted by utilising various levels of sodium selenite and organic selenium by Rao et al., 2013 (0, 0.1, 0.2, 0.3 and $0.4 \mathrm{mg}$ $/ \mathrm{kg}$ diet), Rajashree et al., 2014 (0.25 and 0.5 $\mathrm{mg} / \mathrm{kg})$, Dalia et al., $2017(0.3 \mathrm{mg} / \mathrm{kg})$ and Ravindran and Elliott, $2017(0.3 \mathrm{mg} / \mathrm{kg})$ reported no significant difference in FCR between treatment groups. Habibian et al., (2014) reported similar FCR for broiler birds supplemented with $0,0.5$ and $1 \mathrm{mg} / \mathrm{kg} \mathrm{Se}$ in feed reared in thermo neutral and heat stressed environment.

Study on FCR in broilers as influenced by nano selenium supplementation at 0.0, 0.3, $0.5,1.0$, or $2.0 \mathrm{mg} / \mathrm{kg}$ to the basal diet (Cai $e t$ al., 2012) revealed no significant difference between treatments. Moghaddam et al., (2017) and $\mathrm{Li}$ et al., (2018) supplemented $0.3 \mathrm{mg}$ $\mathrm{Se} / \mathrm{kg}$ as organic selenium and nano selenium in chicken feed and observed no significant difference in FCR.

Against the current study, improved FCR was reported in earlier experiments by supplementing inorganic and organic selenium to basal diet at $0.05,0.15$ and $0.25 \mathrm{mg} / \mathrm{kg}$ level (Wang et al., 2016) and at $0.3 \mathrm{mg} / \mathrm{kg}$ level (Zia et al., 2017) to the chicken feed. Similarly, Roch et al., (2000), Swain et al., (2000), Choct et al., (2004), Naylor et al., (2009), Niu et al., (2009) reported improved FCR of broilers supplemented with organic source of selenium than inorganic selenium supplemented groups and control group.
Earlier studies reported improved FCR in broiler chicken supplemented with nano selenium supplemented at $0.3 \mathrm{mg} / \mathrm{kg}$ diet (Zhou and Wang, 2011) and at $0.5 \mathrm{mg} / \mathrm{kg}$ (Bagheri et al., 2015) level in feed. Selim et al., (2015) revealed better FCR for organic Se $(0.15,0.3 \mathrm{mg} / \mathrm{kg})$ and nano $\mathrm{Se}(0.3 \mathrm{mg} / \mathrm{kg})$ supplemented groups than $0.15 \mathrm{mg} / \mathrm{kg}$ inorganic selenium supplemented group.

Mahmoud et al., (2016) noted improved FCR in heat stressed birds by supplementing nano selenium at $0.3 \mathrm{mg} / \mathrm{kg}$ level in feed, while in another study by Safdari-Rostamabad et al., (2017) supplementation of $1.2 \mathrm{mg} / \mathrm{kg}$ Nano selenium alleviated the adverse effects of heat shock on the FCR of heat stressed-broilers. In the present study, birds were not subjected to any additional stress condition which may resulted in similar FCR in Giriraja birds.

\section{Antioxidant status of birds}

Effect of supplementation of sodium selenite, selenium yeast and nano selenium on antioxidant status of birds measured through activity of SOD, GPx, CAT and TBARS value (Table 5) was differed significantly $(\mathrm{P} \leq 0.05)$ between treatments. Activity of SOD was significantly $(\mathrm{P} \leq 0.05)$ higher in all selenium enriched groups than the non-supplemented control group.

Activity of SOD was similar among inorganic, organic and nano selenium supplemented groups. GPx activity was significantly $(\mathrm{P} \leq 0.05)$ improved by supplementation of sodium selenite at $300 \mathrm{ppb}$ level, selenium yeast and nano selenium at 150 and $300 \mathrm{ppb}$ level than control group. Activity of catalase enzyme was significantly increased in $300 \mathrm{ppb}$ sodium selenite, selenium yeast and nano selenium supplemented groups. TBARS value was decreased significantly $(\mathrm{P} \leq 0.05)$ by supplementation of selenium yeast and nano selenium at 150 and $300 \mathrm{ppb}$ level. 
Table.1 Description of the experimental groups, sources and levels of selenium supplemented

\begin{tabular}{|c|l|l|c|}
\hline \multicolumn{2}{|c|}{ Experiment group } & \multicolumn{1}{|c|}{ Experiment diet } & Levels of selenium \\
\hline $\mathrm{T}_{1}$ & Control & Basal diet & Nil \\
\hline $\mathrm{T}_{2}$ & SS150 & Basal diet $+\mathrm{SS}$ & $150 \mathrm{ppb}$ \\
\hline $\mathrm{T}_{3}$ & SS300 & Basal diet $+\mathrm{SS}$ & $300 \mathrm{ppb}$ \\
\hline $\mathrm{T}_{4}$ & SY150 & Basal diet $+\mathrm{SY}$ & $150 \mathrm{ppb}$ \\
\hline $\mathrm{T}_{5}$ & SY300 & Basal diet $+\mathrm{SY}$ & $300 \mathrm{ppb}$ \\
\hline $\mathrm{T}_{6}$ & NS50 & Basal diet + NS & $50 \mathrm{ppb}$ \\
\hline $\mathrm{T}_{7}$ & NS150 & Basal diet + NS & $150 \mathrm{ppb}$ \\
\hline $\mathrm{T}_{8}$ & NS300 & Basal diet + NS & $300 \mathrm{ppb}$ \\
\hline
\end{tabular}

SS- Sodium Selenite, SY-Selenium Yeast, NS- Nano Selenium

Table.2 Effect of supplementation of SS, SY and NS on weekly cumulative body weight (g) of Giriraja chicken

\begin{tabular}{|l|l|c|c|c|c|}
\multicolumn{2}{|c|}{ Treatment groups } & \multicolumn{5}{|c|}{ Mean body weight (g) } \\
\cline { 3 - 6 } & & Day 1 & Day 21 & Day 42 & Day 56 \\
\hline $\mathrm{T}_{1}$ & Control & $40.36 \pm 0.81$ & $335.36 \pm 6.21$ & $991.52 \pm 9.97$ & $1445.25 \pm 15.70$ \\
\hline $\mathrm{T}_{2}$ & SS150 & $40.39 \pm 0.39$ & $336.65 \pm 6.71$ & $984.70 \pm 9.85$ & $1453.64 \pm 25.36$ \\
\hline $\mathrm{T}_{3}$ & SS300 & $40.09 \pm 0.30$ & $345.26 \pm 4.71$ & $1007.58 \pm 18.05$ & $1472.78 \pm 24.04$ \\
\hline $\mathrm{T}_{4}$ & SY150 & $40.06 \pm 0.66$ & $356.60 \pm 6.43$ & $1027.64 \pm 18.17$ & $1509.85 \pm 30.32$ \\
\hline $\mathrm{T}_{5}$ & SY300 & $39.80 \pm 0.23$ & $356.34 \pm 3.51$ & $1038.59 \pm 14.58$ & $1528.06 \pm 18.34$ \\
\hline $\mathrm{T}_{6}$ & NS50 & $39.46 \pm 0.70$ & $334.79 \pm 7.57$ & $988.64 \pm 10.85$ & $1453.67 \pm 25.72$ \\
\hline $\mathrm{T}_{7}$ & NS150 & $39.67 \pm 0.84$ & $351.75 \pm 8.53$ & $1019.72 \pm 20.38$ & $1483.77 \pm 38.39$ \\
\hline $\mathrm{T}_{8}$ & NS300 & $39.97 \pm 0.15$ & $352.34 \pm 4.80$ & $1039.92 \pm 12.43$ & $1507.36 \pm 13.66$ \\
\hline
\end{tabular}

Table.3 Effect of supplementation of SS, SY and NS on cumulative feed intake (g) of Giriraja chicken

\begin{tabular}{|c|c|c|c|c|}
\hline \multirow{2}{*}{ Treatment groups } & \multicolumn{3}{|c|}{ Cumulative feed intake (g) } \\
\cline { 3 - 5 } & & Day 21 & Day 42 & Day 56 \\
\hline $\mathrm{T}_{1}$ & Control & $494.08 \pm 5.28$ & $1859.13 \pm 3.24$ & $3056.00 \pm 1.48$ \\
\hline $\mathrm{T}_{2}$ & SS150 & $477.63 \pm 11.35$ & $1854.56 \pm 3.58$ & $3052.40 \pm 1.68$ \\
\hline $\mathrm{T}_{3}$ & SS300 & $490.56 \pm 9.47$ & $1853.69 \pm 2.03$ & $3051.35 \pm 1.56$ \\
\hline $\mathrm{T}_{4}$ & SY150 & $485.23 \pm 7.96$ & $1858.31 \pm 2.81$ & $3052.94 \pm 1.27$ \\
\hline $\mathrm{T}_{5}$ & SY300 & $489.71 \pm 6.77$ & $1858.79 \pm 2.08$ & $3052.92 \pm 1.94$ \\
\hline $\mathrm{T}_{6}$ & NS50 & $500.98 \pm 3.00$ & $1859.63 \pm 0.92$ & $3053.54 \pm 1.28$ \\
\hline $\mathrm{T}_{7}$ & NS150 & $493.54 \pm 9.72$ & $1856.02 \pm 2.69$ & $3052.31 \pm 2.66$ \\
\hline $\mathrm{T}_{8}$ & NS300 & $479.33 \pm 11.52$ & $1858.06 \pm 3.08$ & $3052.65 \pm 2.57$ \\
\hline
\end{tabular}


Table.4 Effect of supplementation of SS, SY and NS on cumulative feed conversion ratio of Giriraja chicken

\begin{tabular}{|c|l|c|c|c|}
\multicolumn{2}{|c|}{$\begin{array}{c}\text { Treatment } \\
\text { groups }\end{array}$} & \multicolumn{2}{|c|}{ Cumulative feed conversion ratio } \\
\hline $\mathrm{T}_{1}$ & Control & $1.68 \pm 0.05$ & $1.96 \pm 0.02$ & $2.18 \pm 0.02$ \\
\hline $\mathrm{T}_{2}$ & SS150 & $1.62 \pm 0.06$ & $1.97 \pm 0.02$ & $2.17 \pm 0.04$ \\
\hline $\mathrm{T}_{3}$ & SS300 & $1.61 \pm 0.03$ & $1.92 \pm 0.03$ & $2.13 \pm 0.04$ \\
\hline $\mathrm{T}_{4}$ & SY150 & $1.54 \pm 0.04$ & $1.88 \pm 0.03$ & $2.08 \pm 0.04$ \\
\hline $\mathrm{T}_{5}$ & SY300 & $1.55 \pm 0.03$ & $1.86 \pm 0.03$ & $2.05 \pm 0.02$ \\
\hline $\mathrm{T}_{6}$ & NS50 & $1.70 \pm 0.04$ & $1.96 \pm 0.02$ & $2.16 \pm 0.04$ \\
\hline $\mathrm{T}_{7}$ & NS150 & $1.59 \pm 0.05$ & $1.90 \pm 0.04$ & $2.12 \pm 0.05$ \\
\hline $\mathrm{T}_{8}$ & NS300 & $1.54 \pm 0.04$ & $1.87 \pm 0.02$ & $2.08 \pm 0.02$ \\
\hline
\end{tabular}

Table.5 Effect of supplementation of SS, SY and NS on Antioxidant status of bird

\begin{tabular}{|c|c|c|c|c|c|}
\hline \multicolumn{2}{|c|}{$\begin{array}{c}\text { Treatment } \\
\text { groups }\end{array}$} & \multicolumn{3}{|c|}{ Liver } & Breast Muscle \\
\hline $\mathrm{T}_{1}$ & Control & $17.45 \pm 0.29^{\mathrm{b}}$ & $39.99 \pm 1.90^{\mathrm{b}}$ & $8.41 \pm 0.95^{\mathrm{b}}$ & $0.99 \pm 0.10^{\mathrm{a}}$ \\
\hline $\mathrm{T}_{2}$ & SS150 & $18.53 \pm 0.57^{\mathrm{a}}$ & $43.92 \pm 0.62^{\mathrm{ab}}$ & $9.56 \pm 0.39^{\mathrm{ab}}$ & $0.95 \pm 0.11^{\mathrm{a}}$ \\
\hline $\mathrm{T}_{3}$ & SS300 & $19.32 \pm 0.34^{\mathrm{a}}$ & $47.12 \pm 2.02^{\mathrm{a}}$ & $11.52 \pm 0.46^{\mathrm{a}}$ & $0.81 \pm 0.11^{\mathrm{ab}}$ \\
\hline $\mathrm{T}_{4}$ & SY150 & $19.24 \pm 0.53^{\mathrm{a}}$ & $46.54 \pm 3.77^{\mathrm{a}}$ & $10.41 \pm 0.56^{\mathrm{ab}}$ & $0.59 \pm 0.11^{\mathrm{b}}$ \\
\hline $\mathrm{T}_{5}$ & SY300 & $19.45 \pm 0.34^{\mathrm{a}}$ & $48.17 \pm 1.84^{\mathrm{a}}$ & $11.67 \pm 0.42^{\mathrm{a}}$ & $0.56 \pm 0.07^{\mathrm{b}}$ \\
\hline $\mathrm{T}_{6}$ & NS50 & $19.36 \pm 0.29^{\mathrm{a}}$ & $44.27 \pm 0.57^{\mathrm{ab}}$ & $10.50 \pm 1.10^{\mathrm{ab}}$ & $0.89 \pm 0.04^{\mathrm{ab}}$ \\
\hline $\mathrm{T}_{7}$ & NS150 & $19.38 \pm 0.13^{\mathrm{a}}$ & $49.47 \pm 2.11^{\mathrm{a}}$ & $10.65 \pm 0.42^{\mathrm{ab}}$ & $0.56 \pm 0.16^{\mathrm{b}}$ \\
\hline $\mathrm{T}_{8}$ & NS300 & $19.24 \pm 0.29^{\mathrm{a}}$ & $48.67 \pm 2.07^{\mathrm{a}}$ & $11.91 \pm 1.17^{\mathrm{a}}$ & $0.55 \pm 0.14^{\mathrm{b}}$ \\
\hline
\end{tabular}

Units: SOD: U/min $/ \mathrm{mg}$ of protein, GPx: $\mu$ moles of Glutathione utilised $/ \mathrm{min} / \mathrm{mg}$ of protein,

CAT: $\mu$ moles of $\mathrm{H}_{2} \mathrm{O}_{2} / \mathrm{min} / \mathrm{mg}$ of protein, TBARS: $\mathrm{g} / \mathrm{Kg}$ MDA

Selenium supplementation as sodium selenite, selenium yeast and nano selenium resulted in increased activity of SOD, GPx and CAT than non-supplemented control group. Enzyme activity was higher in all $300 \mathrm{ppb}$ selenium enriched feed supplemented groups irrespective of source. Selenium supplementation at 50 and $150 \mathrm{ppm}$ concentration resulted in comparable antioxidant enzyme activity in sodium selenite, selenium yeast and nano selenium supplemented groups. Increased activity of SOD, GPx and CAT was consistent with decreased MDA concentration (TBARS value) in treatment groups which was in agreement with Rao et al., (2013) who stated decreased Lipid peroxidation in plasma along with linearly increased activities of glutathione peroxidase and catalase in blood.

In agreement with the current study, Dalia et al., (2017) reported significant elevation in liver GPx and CAT activity in selenium supplemented treatment groups, with a substantial reduction in malondialdehyde concentration. But enzyme activity was similar between inorganic and organic selenium supplemented groups which were in line with the current study. Earlier studies by Wang et al., (2011), Ozkan et al., (2007), Jiang et al., (2009), Zoidis et al., (2010), Upton et al., (2009), Chen et al., (2013), 
Rajashree et al., (2014), Edens and Sefton (2016), Gogmen et al., (2016) and Bakhshalinejad et al., (2018) observed increased glutathione peroxidase activity in various tissues of broiler such as liver, breast muscle, blood and serum as influenced by supplementation of organic sources of selenium.

Chen et al., (2014) noted significantly higher liver GPx activity in selenium yeast supplemented group than that sodium selenite supplemented group, while Wang et al., (2011), in line with current study, observed similar activity in these two groups. In contrary, Edens, (2002) reported a steady state release of selenium from organic selenium for incorporation into the glutathione peroxidase antioxidant system which resulted in increased GPx activity. Similarly, Yang et al., (2012) stated $155.83 \%$ higher serum glutathione peroxidase activity in $0.3 \mathrm{mg} / \mathrm{kg}$ organic selenium supplemented 42 day old broiler chicken than that in 0.3 $\mathrm{mg} / \mathrm{kg}$ inorganic selenium supplemented group.

Wang et al., (2009) stated that the GPx activity influences the oxidation state of myofibrillar protein and reduce the drip loss by improving the cell membranes integrity. The meat quality is influenced by pre slaughter GPx concentration in live animals and by anti-oxidative stability of carcass (Renerre et al., 1996) which can be effected by selenium supplementation (Liao et al., 2012). Correspondingly, reduced drip loss was noticed in selenium supplemented groups having increased GPx concentration in the current study.

Wang et al., (2011) and Chen et al., (2013) noted significant increase in SOD activity with dietary supplementation of selenium. Yang et al., (2012), Dalia et al., (2017) and Bakhshalinejad et al., (2018) stated that organic and inorganic source of selenium had no obvious effect on SOD which was opposed by Chen et al., (2014) who observed increased SOD activity in organic selenium supplemented group. Broiler chicken fed on selenium deficient diet in an experiment conducted by Cao et al., (2016) revealed significantly reduced SOD and CAT activity in the arteries and veins. But CAT activity reported by Ozkan et al., (2007) was similar between selenium supplemented groups and control.

Mahmoud et al., (2016) revealed higher GPx, SOD and catalase activity in birds supplemented with nano selenium. In a trial conducted by Cai et al., (2012) by supplementing nano selenium to at $0.3 \mathrm{mg} / \mathrm{kg}$ level showed increased glutathione peroxidase activity compared with the birds receiving 0 and $2.0 \mathrm{mg} / \mathrm{kg}$ of nano selenium and was similar to the birds supplemented with $0.3,0.5$, and $1.0 \mathrm{mg} / \mathrm{kg}$ of nanoSelenium. Supplementation of various sources of selenium to chicken, by Mohapatra et al., (2014) revealed higher GPx activity than nonsupplemented group and nano selenium improved GPx and SOD activity than sodium selenite supplemented groups. Similarly, Safdari-Rostamabad et al., (2017), Qu et al., (2017) and Li et al., (2018) observed linearly increased the activity of glutathione peroxidase by dietary supplementation of nano selenium. Contrary to the result obtained for nano selenium supplemented group $\mathrm{Li}$ et al., (2018) noticed no significant change in activity of SOD and catalase enzyme between treatments and control.

In accordance with the results obtained many studies conducted earlier revealed significant reduction in TBARS value in terms of malondialdehyde concentration in breast meat as influenced by selenium supplementation. Edens and Sefton (2016), Dalia et al., (2017) and Bakhshalinejad et al., (2018) obtained 
significantly lesser malondialdehyde concentration for Selenium supplemented group than negative control group. Significant decrease in TBARS value as influenced by selenium yeast than sodium selenite was reported by Sevcikova et al., (2006), Jokic et al., (2009), Hosseini-Mansoub (2011), Taulescu et al., (2011), Wang et al., (2011), Boiago et al., (2014), Chen et al., (2014), Delles et al., (2014), Salami et al., (2015) and Ravindran and Elliott (2017). Significantly decreased TBARS value was recorded at $0.15 \mathrm{mg} / \mathrm{kg}$ selenium supplementation by Hooge (2007) while TBARS value noted for $0.3 \mathrm{mg} / \mathrm{kg}$ organic selenium was similar to control group. While, Ozkan et al., (2007) and Kralik et al., (2013) did not observe any change in TBARS value due to selenium supplementation.

Earlier studies using nano selenium was also in agreement with current trial results. A similar study conducted by Visha et al., (2017) and Li et al., (2018) reported that dietary supplementation of selenium yeast or selenomethionine and nano selenium significantly decrease the concentration of malondialdehyde in serum compared with the sodium selenite group. Cai et al., (2012) and Moghaddam et al., (2017) conducted a study by supplementing nano selenium as a feed supplement in broiler chicken and reported significant reduction in MDA concentration in liver compared to the control.

Feeding nano selenium to broilers reared at high ambient temperature $\left(35^{\circ} \mathrm{C}\right)$ significantly alleviated the negative effects of heat stress indicated by reduced level of the malondialdehyde content in liver and breast muscle (Mahmoud et al., 2016). Contrary to these studies, Selim et al., (2015) stated that liver and thigh muscle MDA concentration is not affected by inclusion of organic, inorganic and nano forms of selenium in broiler feed at 0.15 and $0.30 \mathrm{mg} / \mathrm{Kg}$ level.
Supplementation of SS, SY and NS up to 300 ppb level did not influence body weight, feed intake and FCR of Giriraja dual purpose chicken reared in deep litter system. Higher levels of selenium (300 ppb) irrespective source improved liver antioxidant enzyme level. Selenium yeast and nano selenium at $150 \mathrm{ppb}$ and $300 \mathrm{ppb}$ level in feed significantly reduced MDA concentration in breast muscle.

\section{Acknowledgement}

Authors are grateful to Karnataka Veterinary, Animal and Fisheries Science University for providing all the facilities required for conducting the experiment.

\section{References}

Bagheri, M., Golchin-Gelehdooni, S., Mohamadi, M. and Tabidian, A., 2015. Comparative effects of nano, mineral and organic selenium on growth performance, immunity responses and total antioxidant activity in broiler chickens. Int. J. Biol. Pharm. Allied Sci., 4: 583-595

Bakhshalinejad, R., Akbari Moghaddam Kakhki, R. and Zoidis, E., 2018. Effects of different dietary sources and levels of selenium supplements on growth performance, antioxidant status and immune parameters in Ross 308 broiler chickens. Br. Poult. Sci., 59(1): 81-91

Boiago, M.M., Borba, H., Leonel, F.R., Giampietro-Ganeco, A., Ferrari, F.B., Stefani, L.M. and Souza, P.A.D., 2014. Sources and levels of selenium on breast meat quality of broilers. Ciência Rural, 44(9): 1692-1698

Cai, S.J., Wu, C.X., Gong, L.M., Song, T., Wu, H. and Zhang, L.Y., 2012. Effects of nano-selenium on performance, meat quality, immune function, oxidation resistance, and tissue selenium content 
in broilers. Poult. Sci., 91(10): 25322539

Calabotta, D.F. and Shermer, W.D., 1985. Controlling feed oxidation can be rewarding. Feedstuffs, 57(48), pp. 2432.

Caliborne, A.L., 1985. Assay of catalase: Handbook of oxygen radical research. Ed. Greenward, RA. CRC Press, Boca Raton, Florida, pp. 283-284

Cao, C., Zhao, X., Fan, R., Zhao, J., Luan, Y., Zhang, Z. and $\mathrm{Xu}$, S., 2016. Dietary selenium increases the antioxidant levels and ATPase activity in the arteries and veins of poultry. Biol. trace element Res., 172(1): 222-227

Chen, G., Wu, J. and Li, C., 2013. The effect of different selenium levels on production performance and biochemical parameters of broilers. Ital. J. of Anim. Sci., 12(4): 79

Chen, G., Wu, J. and Li, C., 2014. Effect of different selenium sources on production performance and biochemical parameters of broilers. $J$. Anim. Physiol. Anim. Nutr., 98(4): 747 754

Da Silva, I.C.M., Ribeiro, A.M.L., CanaL, C.W., Trevizan, L., Macagnan, M., Gonçalves, T.A., Hlavac, N.R.C., De Almeida, L.L. and Pereira, R.A., 2010. The impact of organic and inorganic selenium on the immune system of growing broilers submitted to immune stimulation and heat stress. Revista Brasileira de CiênciaAvícola, 12(4): 247-254

Dalia, A.M., Loh, T.C., Sazili, A.Q., Jahromi, M.F. and Samsudin, A.A., 2017. The effect of dietary bacterial organic selenium on growth performance, antioxidant capacity, and Selenoproteins gene expression in broiler chickens. BMC Vet. Res., 13(1): 254

Davda, J. and Labhasetwar, V., 2002. Characterization of nanoparticle uptake by endothelial cells. Int. J. of pharm., 233(1-2): 51-59

Delles, R.M., Xiong, Y.L., True, A.D., Ao, T. and Dawson, K.A. 2014. Dietary antioxidant supplementation enhances lipid and protein oxidative stability of chicken broiler meat through promotion of antioxidant enzyme activity. Poult. Sci., 93: 1561-1570

Duncan, D.B., 1995. Multiple range and multiple F-tests. Biometrics, 11: 1-42

Edens, F.W. 2002. Practical applications for selenomethionine: broiler breeder reproduction. Proceedings of Alltech's 18th Annual Symposium (K.A. Jacques and T.P. Lyons, eds). Nottingham University Press, UK, pp. 29-42.

Edens, F.W. and Sefton, A.E., 2016. A role for Sel-Plex ${ }^{\mathrm{TM}}$, a source of organic selenium in selenised yeast cell wall protein, as a factor that influences meat stability. J. of Appl. Anim. Nutr., pp. 4.

FDA, 2000. Food additives permitted in feed and drinking water: Selenium yeast. Fed. Reg. 65(109): 35823-35824.

Gangadoo, S., Dinev, I., Chapman, J., Hughes, R.J., Van, T.T.H., Moore, R.J. and Stanley, D., 2018. Selenium nanoparticles in poultry feed modify gut microbiota and increase abundance of Faecalibacterium prausnitzii. Appl. Microbiol. and Biotechnol., 102(3): 1455-1466

Gao, X. and Hiroshi, M., 2005. Peptide- based nanotubes and their applications in bionanotechnology. $A d v$. Mater., 17(17): 2037-2050

Göçmen, R., Yazgan, O. and Cufadar, Y., 2016. Effect of different organic and inorganic selenium levels on performance, selenium concentration of some tissues, glutathione peroxidase enzyme activity and meat quality in broilers. J. Anim. Plant Sci., 26(4): 916923 
Habibian, M., Ghazi, S., Moeini, M.M. and Abdolmohammadi, A., 2014. Effects of dietary selenium and vitamin $\mathrm{E}$ on immune response and biological blood parameters of broilers reared under thermoneutral or heat stress conditions. Int. J. Biometeorol., 58(5): 741-752

Hartemann, P., Hoet, P., Proykova, A., Fernandes, T., Baun, A., De Jong, W., Filser, J., Hensten, A., Kneuer, C., Maillard, J.Y. and Norppa, H., 2015. Nanosilver: Safety, health and environmental effects and role in antimicrobial resistance. Materials Today, 18(3), pp. 122-123.

Hooge, D.M., 2007. Selenium yeast boosts. Feedstuffs, 79(19): 12

Hosseini-mansoub, N., 2011. Influence of organic selenium source on carcass characteristics and oxidative stability of meat of male broilers. Adv. Environ. Biol., 5(7): 1832-1835

Jiang, Z., Lin, Y., Zhou, G., LUO, L., Jiang, S. and CHEN, F., 2009. Effects of dietary selenomethionine supplementation on growth performance, meat quality and antioxidant property in yellow broilers. J. of Agric. and food Chem., 57(20): 9769-9772

Jokić, Ž. Pavlovski, Z., Mitrović, S. and Đermanović, V., 2009. The effect of different levels of organic selenium on broiler slaughter traits. Biotechnol. in Anim. Husbandry, 25(1-2): 23-34

Kim, Y. Y., and D. C. Mahan. 2001. Comparative effects of high dietary levels of organic and inorganic selenium on selenium toxicity of growing-finishing pigs. J. Anim. Sci., 79: 942-948

Kralik, Z., Kralik, G., Biazik, E., Straková, E. and Suchý, P., 2013. Effects of organic selenium in broiler feed on the content of selenium and fatty acid profile in lipids of thigh muscle tissue. Acta Veterinaria Brno, 82(3): 277-282

Li, J.L., Zhang, L., Yang, Z.Y., Zhang, Z.Y., Jiang, Y., Gao, F. and Zhou, G.H., 2018. Effects of different selenium sources on growth performance, antioxidant capacity and meat quality of local Chinese Subei chickens. Biol. trace element Res., 181(2): 340-346

Liao, C.D., Hung, W.L., Jan, K.C., Yeh, A.I., Ho, C.T. and Hwang, L.S., 2010. Nano/sub-microsized lignan glycosides from sesame meal exhibit higher transport and absorption efficiency in Caco-2 cell monolayer. Food Chem., 119(3): 896-902

Liao, X., Lu, L., Li, S., Liu, S., Zhang, L., Wang, G., Li, A. and Luo, X., 2012. Effects of selenium source and level on growth performance, tissue selenium concentrations, antioxidation, and immune functions of heat-stressed broilers. Biol. trace element Res. 150(1-3): 158-165

Lowry, O.H., Rosebrough, N.J., Farr, A.L. and Randall, R.J., 1951. Protein measurement with the Folin phenol reagent. J. of Biol. Chem., 193(1): 265275

Mahmoud H, E.D., IJIRI, D., Ebeid, T.A. and Ohtsuka, A., 2016. Effects of dietary nano-selenium supplementation on growth performance, antioxidative status, and immunity in broiler chickens under thermoneutral and high ambient temperature conditions. The J. of Poult. Sci., 53(4): 274-283

Marklund, S. and Marklund, G., 1974. Involvement of the superoxide anion radical in the autoxidation of pyrogallol and a convenient assay for superoxide dismutase. The FEBSJ., 47(3): 469-474

Moghaddam, A.Z., Hamzekolaei, M.M., Khajali, F. and Hassanpour, H., 2017. Role of Selenium from Different Sources in Prevention of Pulmonary 
Arterial Hypertension Syndrome in Broiler Chickens. Biol. trace element Res., 180(1): 164-170

Mohapatra, P., Swain, R.K., Mishra, S.K., Behera, T., Swain, P., Behura, N.C., Sahoo, G., Sethy, K., Bhol, B.P. and Dhama, K., 2014. Effects of dietary nano-selenium supplementation on the performance of layer grower birds. Asian J. Anim. Vet. Adv., 9: 641-652

Naylor, A., Ravindran, V., Ravindran, G., Thomas, D.V., Kocher, A. and Sacranie, A., 2009. Selenium form and function: impact of Sel-Plex ${ }^{\circledR}$ on broiler efficiency and meat quality. In Proceedings of the 20th Australian Poultry Science Symposium, 9-11th February 2009, Poultry Research Foundation, Sydney, New South Wales, Australia, pp 70-72

Niu, Z., Liu, F., Yan, Q. and Li, L., 2009. Effects of different levels of selenium on growth performance and immunocompetence of broilers under heat stress. Arch. of Anim. Nutr., 63(1): 56-65

NRC. 1994. Nutrient Requirements of Poultry. $9^{\text {th }}$ rev. ed. National Academic Press, Washington, DC.

Özkan, S., Malayoğlu, H.B., Yalcin, S., Karadaş, F., Koçtürk, S., Cabuk, M., Oktay, G., Özdemir, S., Özdemir, E. and Ergül, M., 2007. Dietary vitamin E ( $\alpha$-tocopherol acetate) and selenium supplementation from different sources: Performance, ascites-related variables and antioxidant status in broilers reared at low and optimum temperatures. British poultry science, 48(5), pp. 580593.

Payne, R.L. and Southern, L.L., 2005. Comparison of inorganic and organic selenium sources for broilers. Poult. Sci., 84(6): 898-902

Qu, W., Yang, J., Sun, Z., Zhang, R. and Zhou, F., 2017. Effect of Selenium
Nanoparticles on Anti-Oxidative Level, Egg Production and Quality and Blood Parameter of Laying Hens Exposed to Deoxynivalenol. J. Anim. Res. Nutr., 2(1): 1

Rajashree, K., Muthukumar, T. and Karthikeyan, N., 2014. Influence of Inorganic and Organic Selenium Sources on Broiler Performance and Meat Quality. Iranian J. of Appl. Anim. Sci., 4(1): 151-157

Rao, S.V.R., Prakash, B., Raju, M.V.L.N., Panda, A.K., Poonam, S. and Murthy, O.K., 2013. Effect of supplementing organic selenium on performance, carcass traits, oxidative parameters and immune responses in commercial broiler chickens. Asian-Australasian J. of Anim. Sci., 26(2): 247

Ravindran, V. and Elliott, S., 2017. Influence of selenium source on the performance, feathering and meat quality of broilers. J. of Appl. Anim. Nutr., 5: 1-8

Renerre, M., Dumont, F. and Gatellier, P., 1996. Antioxidant enzyme activities in beef in relation to oxidation of lipid and myoglobin. Meat Sci., 43(2): 111-121

Roch, G., Boulianne, M. and De Roth, L., 2000. Effects of dietary vitamin $\mathrm{E}$ and selenium source on incidence of ascites, growth performance and blood parameters cold-stressed broilers. Poult. Sci., 79(1): 41

Rotruck, J.T., Pope, A.L., Ganther, H.E., Swanson, A.B., Hafeman, D.G. and Hoekstra, W., 1973. Selenium: biochemical role as a component of glutathione peroxidase. Science, 179(4073): 588-590

Safdari-Rostamabad, M., Hosseini-Vashan, S.J., Perai, A.H. and Sarir, H., 2017. Nanoselenium supplementation of heatstressed broilers: effects on performance, carcass characteristics, blood metabolites, immune response, antioxidant status, and jejunal 
morphology. Biol. trace element Res., 178(1): 105-116

Salami, S.A., Majoka, M.A., Saha, S., Garber, A. and Gabarrou, J.F., 2015. Efficacy of dietary antioxidants on broiler oxidative stress, performance and meat quality: science and market. Avian Biol. Res., 8(2): $65-78$

Selim, N.A., Radwan, N.L., Youssef, S.F., Eldin, T.S. and ELWAFA, S.A., 2015. Effect of inclusion inorganic, organic or nano selenium forms in broiler diets on: 1-growth performance, carcass and meat characteristics. Int. J. of Poult. Sci., 14(3): 135-143

Ševčíková, S., Skřivan, M., Dlouhá, G. and Koucký, M., 2006. The effect of selenium source on the performance and meat quality of broiler chickens. Czech J. Anim. Sci., 51(10): 449-457

Snedecor, G. W. and Cochran, W. G. (1994). Statistical Methods. ( $8^{\text {th }}$ ed.) Affiliated East- West Press, Pvt. Ltd, New Delhi, India. $313 p$.

Srimongkol, C., Angkanaporn, K. and Kijparkorn, S., 2004, May. Effect of selenium supplementation on performance, thyroid hormone levels, antioxidant enzyme and disaccharidase activities in broilers. Nutritional Biotechnology in the Feed and Food Industry. In Proceedings of the 20th Annual Symposium, p13

Sunde, R.A., 1994. Intracellular glutathione peroxidases - structure, regulation, and function. In Selenium in biology and human health (pp. 45-77). Springer, New York, NY.

Surai, P.F., 2002. Selenium in poultry nutrition 1. Antioxidant properties, deficiency and toxicity. World's Poultry Science Journal, 58(3), pp. 333-347.

Swain, B.K., JohrI, T.S. and Majumdar, S., 2000. Effect of supplementation of vitamin $\mathrm{E}$, selenium and their different combinations on the performance and immune response of broilers. Br. Poult. Sci., 41(3): 287-292

Taulescu, C., Mihaiu, M., Bele, C., Matea, C., Dan, S.D., Mihaiu, R. and Lapusan, A., 2011. Antioxidant effect of vitamin $E$ and selenium on omega-3 enriched poultry meat. Bulletin of University of Agricultural Sciences and Veterinary Medicine Cluj-Napoca. Veterinary Medicine, 2: 68

Tayeb, T.I. and Qader, G.K., 2012. Effect of feed supplementation of selenium and vitamin $\mathrm{E}$ on production performance and some hematological parameters of broiler. Kahramanmaraş Sütçü İmam Üniversitesi Doğa Bilimleri Dergisi, 15(3): 46-56

Upton, J.R., Edens, F.W. and Ferket, P.R., 2009. The effects of dietary oxidized fat and selenium source on performance, glutathione peroxidase, and glutathione reductase activity in broiler chickens. $J$. of Appl. Poultry Res., 18(2): 193-202

Visha, P., Nanjappan, K., Selvaraj, P., Jayachandran, S. and Thavasiappan, V., 2017. Influence of Dietary Nanoselenium Supplementation on the Meat Characteristics of Broiler Chickens. Int. J. Curr. Microbiol. App. Sci., 6(5): 340-347

Wang, Y., Wang, H. and Zhan, X., 2016. Effects of different dl- selenomethionine and sodium selenite levels on growth performance, immune functions and serum thyroid hormones concentrations in broilers. $J$. of Anim. Physiol. and Anim. Nutr., 100(3): 431-439

Wang, Y., Zhan, X., Zhang, X., Wu, R. and Yuan, D., 2011. Comparison of different forms of dietary selenium supplementation on growth performance, meat quality, selenium deposition, and antioxidant property in broilers. Biological Trace Element Research, 143(1), pp. 261-273. 
Wang, Z.G., Pan, X.J., Peng, Z.Q., Zhao, R.Q. and Zhou, G.H., 2009. Methionine and selenium yeast supplementation of the maternal diets affects color, waterholding capacity, and oxidative stability of their male offspring meat at the early stage. Poult. Sci., 88(5): 1096-1101

Witte, V.C., Krause, G.F. and Bailey, M.E., 1970. A new extraction method for determining 2- thiobarbituric acid values of pork and beef during storage. J. of food Sci., 35(5): 582-585.

Xu, S., Lee, S.H., Lillehoj, H.S., Hong, Y.H. and BRAVO, D., 2015. Effects of dietary selenium on host response to necrotic enteritis in young broilers. Res. in Vet. Sci., 98: 66-73

Yang, Y.R., Meng, F.C., Wang, P., Jiang, Y.B., Yin, Q.Q., Chang, J., Zuo, R.Y., Zheng, Q.H. and Liu, J.X., 2012. Effect of organic and inorganic selenium supplementation on growth performance, meat quality and antioxidant property of broilers. African J. of Biotechnol., 11(12): 3031-3036

Zha, L.Y., Xu, Z.R., Wang, M.Q. and Gu, L.Y., 2008. Chromium nanoparticle exhibits higher absorption efficiency than chromium picolinate and chromium chloride in Caco- 2 cell monolayers. J. of Anim. Physiol. and Anim. Nutr., 92(2): 131-140

Zhang, J. S., Gao, X.Y., Zhang, L.D. and Bao, Y.P., 2001. Biological effects of a nano red elemental selenium. Biofactors, 15(1): 27-38

Zhou, X. and Wang, Y., 2011. Influence of dietary nano elemental selenium on growth performance, tissue selenium distribution, meat quality, and glutathione peroxidase activity in Guangxi Yellow chicken. Poult. Sci., 90(3): 680-686

Zia, W.M., Khalique, A., Naveed, S., Hussain, J., Muhammad, N. and Ahmad, S., 2017. Comparative evaluation of influence of dietary organic and inorganic selenium supplement on growth performance of indigenous Aseel chickens. Indian J. of Anim. Res., 51(3): 478-488

Zoidis, E., Pappas, A.C., Georgiou, C.A., Komaitis, E. and Feggeros, K., 2010. Selenium affects the expression of GPx4 and catalase in the liver of chicken. Comp. Biochem. Physiol. B Biochem. and Mol. Biol., 155(3): 294300

\section{How to cite this article:}

Prasoon S., Jayanaik, V. Malathi, C.S. Nagaraja and Narayanaswami, H.D. 2018. Effects of Dietary Supplementation of Inorganic, Organic and Nano Selenium on Antioxidant Status of Giriraja Chicken. Int.J.Curr.Microbiol.App.Sci. 7(08): 2399-2412. doi: https://doi.org/10.20546/ijcmas.2018.708.242 